Article

\title{
How does Human Capital Heterogeneity Affect Chinese Enterprises' Direct Investment in Africa?
}

\author{
Chen Gao ${ }^{1}$, Dingsheng Zhang ${ }^{1, i}$, Mingshuo $\mathrm{Cao}^{2}$ and Ya Wen ${ }^{3}$ * \\ 1 China Economics and Management Academy, Central University of Finance and Economics, Beijing 100081, China; \\ gaoc9206@163.com (C.G.) dszhang@cufe.edu.cn(D.Z.) \\ 2 Freeman School of Business, TulaneUniversity, New Orleans, LA70118, U.S. \\ 3 School of Economics, Beijing Technology and Business University, Beiïng 100048, China; \\ * Correspondence: weny9306@163.com; Tel:. 19801282951
}

\begin{abstract}
Is human capital heterogeneity a decisive factor for Chinese enterprises to invest in Africa? Based on the Outward Foreign Direct Investment (OFDI) data of Chinese enterprises in 37 African countries from 2007 to 2017, this paper using the FGLS model, is the empirical analysis of the mechanism and effect of the human capital heterogeneity of host countries on OFDI location selection. The human capital heterogeneity can bedivided into four dimensions: scale, quality, cost and structure, which can be measured by health level, education level, wage level, child dependency ratio and old-age dependency ratio. The results show that: (1) the host country's human capital scale and child dependency ratio structure have a significant positive impact on decision-making for OFDI; (2) the cost of human capital and the structure of old-age dependency ratio are negatively correlated with the inflow of OFDI; (3) different from the existing conclusions, the quality of human capital will inhibit the inflow ofOFDI in the sample period; (4) the extended test shows that the quality of human capital has a significant positive impact on OFDI decision-making. The results of robustness test are reliable. Finally, according to the conclusion of this paper, policy recommendations are put forward.
\end{abstract}

Keywords: Africa; Human Capital; OFDI; Heterogeneity

\section{Introduction}

China has become Africa's most important economic cooperation partner, since the establishment of the Forum on China-Africa Cooperation has strengthened bilateral relations. In 2003, China's direct investment in Africa was less than USD 100 million. By 2020, China's direct investment in Africa reach nearly USD 3 billion. Human capital is an essential production factor of a country and has great influence on foreign enterprises making investment decisions. In this way, is the human capital heterogeneity a decisive factor, when Chinese enterprises try to invest in Africa? How to deal with the impact of human capital in host country is also a question enterprises often consider. In 2014, the outbreak of Ebola in West Africa, causing a large number of foreign companies to withdraw their investment. Factors such as the quality and health condition of human capital in host country have always influenced foreign companies making investment decisions.

The heterogeneity of human capital comes from the observation of different output by different labor forces. In terms of classification study, it is generally accepted that employees can be divided into high-skilled human capital and low-skilled human capital according to their education status or training time [1]. If a country has sufficient human capital or can master high technology, and can create technology spillover effect on the local market, the country can be thought of as having high-skilled human capital. Conversely, if a country's human capital is not sufficient or skilled enough, and can only participate in ordinary labour in the local market, it can be called low-skilled human capital [2]. Bellante[3] established a Flow Model of human capital heterogeneity, measured the heterogeneity of human capital by indicators such as working years and education levels, and pointed out that the influencing factors of the two were different. In terms of the mobility of high-skilled and low-skilled human capital, some scholars have found through the Self-Selection Model and Income Distribution Model that income level and technical rate of return will affect the mobility of human capital [4]. The results of Dunlevy's [5] study showed that human capital with rapid mobility generally had a high level of education. According to labor skills, Li [6] divided human capital into four 
categories: general human capital, skilled human capital, managerial human capital and entrepreneurial human capital.

Going through research on the relationship between human capital and Foreign Direct Investment (FDI), we found domestic and foreign scholars both agree that human capital affects corporate's direct investment in foreign countries. However, in China, the systematic research on the heterogeneity of human capital in host countries, especially the research on the heterogeneity of human capital in Africa, is still insufficient. The structure of the human capital market can influence operating conditions and the FDI of multinational companies, found by Vanhonacker and Pan [7]. When studying the direct investment activities of Italian companies in Central and Eastern Europe, Majocchi and Strange [8] pointed out that the availability of human capital is an important factor in the choice of FDI location. Behname [9] found that the wage level of human capital will have an impact on the inflow of FDI through research on the influencing factors of FDI in Central and Eastern Europe. Jaeck and Kim [10] studied the political economy of the interaction between FDI and human capital market policies. This political and economic framework shows that, for major powers, FDI liberalization policies could lead to deregulation of the human capital market, while for small countries, such policies have increased the rigidity of the human capital market.

Although domestic documents have done a lot of research on the influencing factors of FDI, there are few analyses from the perspective of the heterogeneity of human capital in the host country. Even if human capital is considered, it normally involves only this one aspect alone [11], which lacks a more systematic and comprehensive discussion. In the research of human capital heterogeneity and FDI in our country, Lin [12] analyzes the relationship between human capital heterogeneity and FDI in China from perspectives of working age, wage level and different stages of education. In terms of corporate OFDI, Feng et al. [13] pointed out that due to the wages have increased rapidly in recent years and leading to higher and higher manufacturing costs, countries with low human capital costs have become important FDI locations for China. Wu and Huang [14] compared the difference between upstream and downstream investments, and found that the cost of human capital in the host country has no significant impact on the upstream investment of Chinese enterprises, but has a significant inhibitory effect on the downstream investment of enterprises.

In summary, the issue of human capital heterogeneity has aroused widespread concern, which affects corporate investment decisions. As for empirical tests, the research conclusions are not all consistent due to the classification principles or the characteristics of the sample itself are different. According to the survey, $89 \%$ of the employees of Chinese companies in Africa are local residents from host countries. However, the research on Chinese companies' investment in Africa is not yet satisfactory. It is believed that the results of this research have high guiding value for the implementation of the China-Africa Cooperation Forum Beijing Action Plan (2019-2021). To this end, this article selects 37 countries in Africa as samples to explore the impact of human capital heterogeneity on the location selection of OFDI.

\section{Theoretical Background and Research Hypothesis}

\subsection{The impact of human capital scale of host country on the OFDI of the enterprises}

As a production factor, human capital's health level plays an important role in a country's manufacturing activities and economic development. Generally speaking, the scale of human capital is measured by quantity, and the health level can better characterize it [15]. Healthy human capital status can enhance marginal productivity, ensure that employees gain more work experience and longer working years, and have a stabilizing effect on human capital scale [16]. Without doubt, the high health level of employees' family members can also increase the attendance rate of human capital. Bhargava [17], Savedoff and Schultz [18] have respectively pointed out that health level has a positive effect on economic growth and productivity. The health level of a country's human capital significantly affects its level of employment, and also promotes the chances of employment, thereby expanding the scale of human capital. Alsan et al. [19] pointed out that the health level of human capital in the host country can significantly promote FDI from other countries. Chinese companies are more willing to invest in host countries 
with relatively high levels of economic development [20], which perhaps is related to the scale of human capital in the host country. Based on this, the health level is selected to measure the scale of human capital. Hence, this research proposes the following hypotheses:

Hypothesis 1. The health level of human capital in the host country will promote the inflow of corporate OFDI.

\subsection{The impact of host country's human capital quality on the OFDI of the enterprise}

There is no doubt that the development of education was the foundation to determine the quality of a country's human capital. Place considerable value on education can bring more human resources to the market, and strengthen its human capital quality and innovation ability, thereby increasing the productivity of enterprises [21]. Education level plays an important role in alleviating the uneven economic development and narrowing the income gap [22]. Coulombe and Tremblay [23] researched on Canadian education's rate of return and came to the conclusion that higher education investment has a significant role in promoting economic development. Wang [24] studied the relationship between education structure and economic growth through the MRW model and found that human capital will show an upward trend with the improvement of education level. The above research fully shows that education promotes the improvement of human capital quality, thus driving economic development. Therefore, the education level can be used to measure the human capital quality of the host country. When explaining the "Lucas paradox", Lucas proposed three possible reasons: first, the neoclassical theory ignores the heterogeneity of labor quality or human capital in different countries; second, the spillover effect of human capital; third, political risk or incomplete capital market in developing countries. Although the "Lucas Paradox" reveals that capital does not flow from developed countries to developing countries despite the fact that developing countries have lower levels of capital per worker, most scholars believe that human capital plays an important role in attracting foreign investment [11]. Does African human capital quality affect Chinese companies' investment decisions? In this regard, the following hypothesis is proposed:

Hypothesis 2. The education level of the host country and the OFDI of the enterprise present a positive correlation.

\subsection{The impact of human capital cost in host country on OFDI}

The level of wages that measures a country's cost of human capital, is closely related to the economic development situation of a country. Some scholars have revealed that the cost of human capital in China has no significant impact on FDI inflows [25,26]. However, most scholars believe that the cost of human capital in the host country will significantly affect the location selection of FDI and show a negative correlation [27]. Feng et al. [13] found that the cost of human capital has a threshold effect on FDI. An appropriate increase in the cost of human capital can effectively promote the inflow of FDI, nevertheless when the cost of human capital exceeds a certain value, it will inhibit FDI. Liu et al. [28] pointed out that lower wage levels have a significant role in promoting FDI inflows for developing countries, while the same is not true of developed countries. Taking into account that most countries in Africa are actually developing countries, the level of economic development is relatively backward, and the cost of human capital is low, Chinese companies invest in Africa to a certain extent to reduce manufacturing costs. Therefore, the study proposes the following hypotheses:

Hypothesis 3. Lower wages in the host country promote the inflow of Chinese corporates OFDI.

\subsection{The impact of human capital structure of host country on OFDI}

As the development of the economy and society, and the constantly changing age structure of the population, people's investment behaviors such as saving and consumption have changed, which could have a long-term impact on a country's employment, output, inflation, international trade, investment and other aspects [29]. 
Mason [30] studied Asian countries after World War II and he mainly attributed the high economic growth rate to the rapid increase of working-age population, that is, demographic dividends played a promoting role in economic development. Demographic dividends have many influencing factors, but few measuring indicators.

In early time, Bloom and Williamson [31] proposed the concept of demographic dividend, which was measured by population dependency ratio in their research. Looking from the existing literatures, domestic and foreign scholars have conducted in-depth studies on the relationship between population structure and savings, but the conclusions are inconsistent [32]. Developing countries tend to have high Child Dependency Ratio (CDR) and low Old-age Dependency Ratio (ODR). Higher CDR leads to larger marginal propensity to consume, which has the potential to make advantage of demographic dividend and develop economy, thus attracting the inflow of FDI [28]. A high ODR will accelerate the aging phenomenon, thus reducing the per capita savings rate and leading to capital outflow [33]. Therefore, the hypotheses below are proposed:

Hypothesis 4a. The high CDR in the host country promotes the inflow of OFDI;

Hypothesis $\mathbf{4 b}$. The high ODR of the host country inhibits the inflow of OFDI.

\section{Research Design}

\subsection{Variable selection and data source}

This paper studies the impact of human capital heterogeneity in Africa on the OFDI location choice of Chinese enterprises, and selects 37 representative countries in Africa as research samples. 37 sample countries selected in Africa are: Ethiopia, Gabon, Rwanda, the Democratic Republic of the Congo, Tanzania, the Republic of Congo, Uganda, Mozambique, Equatorial Guinea, Mauritius, Cameroon, Madagascar, Nigeria, Malawi, Mali, Benin, Namibia, Tunisia, Egypt, Senegal, Seychelles, South Africa, Liberia, Botswana, Sudan, Niger, Chad, Algeria, Kenya, Ghana, Angola, Lesotho, Mauritania, Zambia, Togo, Morocco and Cote d 'Ivoire. The selected variables and data sources are described as follows:

\subsubsection{Explained Variable}

China's direct investment stock to Africa. The stock value and flow value are the two ways to measure enterprise's OFDI. Chinese enterprises' FDI to Africa is still in the primary stage that the investment flow value is low, and several years of data is missing, therefore the research selects stock value as explained variables, which was from the Statistics Bulletin of China's Foreign Direct Investment (2007-2017). In order to eliminate heteroscedasticity, the research uses logarithmic transformation to process data.

\subsubsection{Core Explanatory Variables}

Human Capital Scale. The national statistical data of African countries is seriously missing, with half of the birth population not registered, and some countries have not conducted population statistics for decades. Considering that there is a lot of missing data on the total human capital quantity of African countries, the human capital scale of host countries is measured by health level. Referred to the research method of Liu et al. [28], this paper adopts life expectancy at birth to represent the health level of a country's human capital, with data from The World Population Prospects released by the United Nations. In order to eliminate heteroscedasticity, the research used logarithmic transformation to process data.

Quality of Human Capital. The education level of a host country is chosen to represent the quality of human capital. The level of education directly reflects the situation of local human resources and thus determines the ability of technological innovation. In this paper, education is measured as a percentage of GNI spent on education, based on data from the World Bank WDI database. The data has been processed with logtransformation.

Cost of Human Capital. The wage level is chosen to represent the cost of human capital. Generally speaking, the lower the wage level of the host country is, the lower the cost of human capital is, and the more it can attract the inflow of foreign capital. In this paper, the national income per capita is used to measure the wage level, and then the human capital cost of the host country is expressed. The data came from the United 
Nations System of National Accounts Database, and log-transformation has been used on the data.

Human capital structure. The dependency ratio is used to measure the human capital structure of the host country. It is divided into two kinds: the first is CDR, which mainly reflects the consumption ability and economic growth ability of a country and is expressed by the percentage of the child population in the working-age population; the second is ODR, which mainly reflects the aging situation of a country's population and is expressed as the percentage of the elderly population in the working-age population. The data was from the World Bank and has been processed with log-transformation to eliminate the effects of heteroscedasticity.

\subsubsection{Control Variables}

Market size. There are three main measures of a country's market size: GDP per capita, GDP, or GDP growth rate. Comparatively speaking, GDP can better reflect the size of a country's market economy. The larger the market size of the host country is, the larger the OFDI scale of the enterprise will be. Referred to the research method of Wang et al. [20], GDP (dollar value) was selected to measure the market size of the host country. The data comes from the United Nations System of National Accounts Database. In order to eliminate heteroscedasticity, the research uses log-transformation to process data.

Distance cost. Distance cost refers to the additional cost caused by distance factors during OFDI, and such cost is inevitable. Generally speaking, the greater the distance cost, the smaller the OFDI scale for an enterprise. According to the existing articles, two methods are commonly used to measure the cost of distance: one is the absolute distance between two capital cities; the second is the use of relative distance. The absolute distance of the first method is a fixed value, but has defects, because the distance cost is constantly changing with the shipping price and it is not applicable to the regression analysis of panel data. Therefore, according to the research method of Jiang and Zhang [34], the relative distance is used to measure the distance cost, that is, the product of the absolute distance between two capital cities and the average international oil price. The distance data between two capitals comes from the CEPII database, and the global oil price data came from the IMF database. To eliminate the effect of heteroscedasticity, the research used logtransformation to process data.

Exchange rate level. The exchange rate of host country is an important determinant of OFDI. The exchange rates of African countries mostly use the direct quotation method. The increase in the exchange rate of the host country indicates the currency appreciation of the investing country. The devaluation of the host country's currency means that the host country's products are cheaper, usually enabling the inflow of foreign investment. The official exchange rate of the host country was adopted, and the data was obtained from the IMF database. The research used log-transformation to process this data.

Trade openness. Stoiana and Filippaios [35] believe that trade barriers will increase the transaction costs for foreign investors, so the host country that an open economy is easier to be known by other countries, and attract the inflow of foreign OFDI. Generally speaking, trade openness has a positive effect on OFDI of enterprises from other countries. The reduction of trade barriers in host countries makes China's efficiency-oriented investors import intermediate products and export finished products. The ratio of commodity trade volume to the GDP of host country was selected to measure trade openness. The data came from the WDI database, and log-transformation has been carried out on the data.

Bilateral trade relations. Bilateral trade relations not only reflect the economic exchanges between China and the host country, but also illustrate enterprises' familiarity with the host country's market. Strong bilateral ties help companies evade trade barriers in host countries and expand overseas markets. In general, there is a positive correlation between the OFDI and the host country's trade dependence on the investing country. In this paper, the bilateral trade volume between China and African countries was selected to measure bilateral trade relationships. The data was from the UNCTAD database, and log-transformation has been carried out on the data.

Infrastructure. Good infrastructure in the host country can effectively reduce the investment and operating costs of multinational enterprises, thus attracting the inflow of foreign capital. A country's infrastructure includes many things: electricity, communications equipment, transportation, Internet users, and so on. A lot of information 
needs to be transmitted during OFDI. Internet users (per 100 people) are selected to measure the condition of infrastructure in the host country. The data is obtained from the ITU World Telecommunication/ICT Development Report and database, and has been processed by log-transformation.

Natural resource endowment. One of the most important motive factors for OFDI is to search for overseas resources. The resource endowment of host country can be measured by the proportion of natural resource export and natural resource reserve. Considering the continuity and availability of relevant data for African countries, refer to the research methods of $\mathrm{Li}$ and Zheng [36], the research selected natural resource rent index which is more favorable than using export proportion to measure the natural resource endowment of the host country. Based on the different export purposes, the proportion of resource export is easy to make incorrect assessment of natural resource endowment. Therefore, the proportion of natural resource rent value in GDP is selected to measure the natural resource endowment of the host country. The data was from the World Bank, and the log-transformation has been carried out on the data.

The descriptive statistics of the above variables are shown in Table 1 and Table 2.

Table 1. Variable declaration

\begin{tabular}{|c|c|c|c|c|}
\hline $\begin{array}{l}\text { Variable } \\
\text { types }\end{array}$ & $\begin{array}{l}\text { Variable } \\
\text { names }\end{array}$ & Explanation & $\begin{array}{l}\text { Expression } \\
\text { Form }\end{array}$ & Data Source \\
\hline $\begin{array}{l}\text { Explained } \\
\text { Variable }\end{array}$ & OFDI & OFDI Stock & $\operatorname{lnOFDI}$ & $\begin{array}{l}\text { Statistics Bulletin of China's Foreign } \\
\text { Direct Investment }\end{array}$ \\
\hline \multirow{5}{*}{$\begin{array}{l}\text { Explanatory } \\
\text { Variable }\end{array}$} & $\begin{array}{l}\text { Human Capital } \\
\text { Scale }\end{array}$ & Health Level & $\operatorname{lnHEA}$ & World Population Prospects \\
\hline & $\begin{array}{c}\text { Human Capital } \\
\text { Quality }\end{array}$ & Educational Level & $\operatorname{lnEDU}$ & WDI Database \\
\hline & $\begin{array}{l}\text { Cost of Human } \\
\text { Capital }\end{array}$ & Wage Level & $\operatorname{lnWAG}$ & $\begin{array}{l}\text { United Nations System of National } \\
\text { Accounts Database }\end{array}$ \\
\hline & \multirow[t]{2}{*}{$\begin{array}{c}\text { Human Capital } \\
\text { Structure }\end{array}$} & Child Dependency Ratio & $\operatorname{lnCDR}$ & World Bank \\
\hline & & Old-Age Dependency Ratio & $\operatorname{lnODR}$ & World Bank \\
\hline \multirow{7}{*}{$\begin{array}{l}\text { Control } \\
\text { Variable }\end{array}$} & Market Size & GDP (US dollar) & $\operatorname{lnGDP}$ & $\begin{array}{l}\text { United Nations System of National } \\
\text { Accounts Database }\end{array}$ \\
\hline & Distance Cost & $\begin{array}{c}\text { Product of the absolute distance } \\
\text { between two capitals city and } \\
\text { the average international oil } \\
\text { price }\end{array}$ & $\operatorname{lnDIS}$ & CEPII Database and IMF Database \\
\hline & $\begin{array}{l}\text { Exchange Rate } \\
\text { Level }\end{array}$ & $\begin{array}{l}\text { Official exchange rate of the host } \\
\text { country }\end{array}$ & $\operatorname{lnEXC}$ & IMF Database \\
\hline & $\begin{array}{c}\text { Trade } \\
\text { Openness Level }\end{array}$ & $\begin{array}{l}\text { Commodity trade volume / } \\
\text { GDP of the host country }\end{array}$ & $\operatorname{lnOPEN}$ & WDI Database \\
\hline & $\begin{array}{l}\text { Bilateral Trade } \\
\text { Relations }\end{array}$ & Bilateral trade volume & $\operatorname{lnTRA}$ & UNCTAD Database \\
\hline & Infrastructure & Internet users (per 100 people) & $\operatorname{lnINT}$ & $\begin{array}{l}\text { ITU World Telecommunication /ICT } \\
\text { Development Report }\end{array}$ \\
\hline & $\begin{array}{c}\text { Natural } \\
\text { Resource } \\
\text { Endowment }\end{array}$ & $\begin{array}{l}\text { Natural resource rents }(\% \text { of } \\
\text { GDP) }\end{array}$ & $\operatorname{lnRES}$ & World Bank \\
\hline
\end{tabular}

Table 2. Descriptive statistics of variables.

\begin{tabular}{ccccc}
\hline Variable names & Mean & Standard & Min & Max \\
\hline OFDI & 9.843 & 1.642 & 4.754 & 13.524 \\
Market Size & 23.699 & 1.378 & 20.421 & 27.066 \\
Distance Cost & 13.552 & 0.333 & 12.672 & 14.072 \\
Exchange Rate Level & 4.535 & 2.134 & -0.067 & 8.192
\end{tabular}




$\begin{array}{ccccc}\text { Trade Openness Level } & 4.026 & 0.448 & 2.375 & 5.055 \\ \text { Bilateral Trade Relations } & 11.771 & 1.562 & 7.08 & 15.691 \\ \text { Infrastructures } & 2.162 & 1.198 & -0.994 & 4.162 \\ \text { Natural Resources } & 2.047 & 1.671 & -6.782 & 4.082 \\ \text { Health Level } & 4.11 & 0.114 & 3.758 & 4.337 \\ \text { Educational Level } & 1.25 & 0.553 & -.163 & 2.275 \\ \text { Wage Level } & 8.193 & 0.991 & 6.328 & 10.266 \\ \text { CDR } & 4.242 & 0.319 & 3.257 & 4.668 \\ \text { ODR } & 1.781 & 0.281 & 1.263 & 2.74\end{array}$

\subsection{Model construction}

Using scale, quality, cost and structure of human capital as the main explanatory variables, this paper studies the four dimensions of human capital heterogeneity's influence on corporate investment. What calls for special attention is that, selecting CDR and ODR to measure the structure of the human capital, the impact of different measures are also different. Therefore, different measuring indexes are successively brought into the model for stepwise regression analysis. Based on the expansion of the gravity model, the natural logarithm form of the model is constructed as follows:

$$
\operatorname{lnOFDI} I_{i t}=\alpha_{0}+\alpha_{1} \ln L A B_{i t}+\alpha_{2} C_{i t}+\beta_{i}+\gamma_{t}+\varepsilon_{i t}
$$

In the model, $i$ represents country, $t$ represents the year of investment; $\beta_{i}$ represents the regional fixed effect, $\gamma_{\mathrm{t}}$ represents the year fixed effect, $\varepsilon_{\text {it }}$ represents the residual term; $\ln L A B$ represents all dimensions of human capital, which includes human capital scale $(\ln H E A)$, human capital quality $(\ln E D U)$, human capital cost $(\ln W A G)$ and human capital structure $\mathrm{CDR}$ and $\mathrm{ODR}(\ln C D R$ and $\ln O D R) ; \mathrm{C}$ represents other controlled factors, including market size $(\ln G D P)$, distance cost $(\ln D I S)$, exchange rate level $(\ln E X C)$, Trade Openness $(\ln O P E N)$, bilateral trade Relationship $(\ln T R A)$, infrastructure $(\ln I N T)$, and Natural resource Endowment $(\ln R E S)$.

\section{Empirical Analysis}

\subsection{Preliminary inspection}

Before the empirical analysis, the effect of multicollinearity among the explanatory variables was tested first. The correlation coefficient matrix of variables is shown in Table 3. Only the correlation coefficient between CDR and ODR is greater than 0.8 , but these two were not tested by the same model, so the correlation is not considered. The correlation coefficients of other variables were all lower than 0.8 , suggesting that there was no significant multicollinearity. For the sake of precision, the variance inflation factor (VIF) of variables was further investigated. It was found that the VIF values of all variables were lower than 8 , and the average VIF value was less than 5 , indicating that there was no multicollinearity among variables.

There are three methods to test panel data: fixed effect, random effect and mixed effect. First, F-test is conducted, and the results reject the null hypothesis, that is, the mixed effects model is rejected. Then the Hausman test was conducted, and the null hypothesis was rejected, indicating that the fixed effects model was better than the random effects model. Therefore, the fixed effects model was used for testing. In consideration of heteroscedasticity and autocorrelation of variables, White test and Wooldridge test were used to perform heteroscedasticity and autocorrelation tests, respectively. Both P values were 0.0000 , which rejected the null hypothesis, indicating heteroscedasticity and autocorrelation problems existed between variables. Therefore, the Feasible Generalized Least Squares (FGLS) method was adopted for the estimation.

Table 3. Correlation coefficient matrix among main variables of the model

\begin{tabular}{c|cccccccccccc}
\hline Variable names & GDP & DIS & EXC & OPEN & TRA & INT & RES & HEA & EDU & WAG & CDR & ODR \\
\hline \multirow{2}{*}{ GDP } & 1.00 & & & & & & & & & & & \\
\cline { 2 - 8 }
\end{tabular}




\subsection{Full sample test}

Firstly, an empirical analysis is conducted on the full sample data of African countries, and the results are shown in Table 4.

Table 4. The regression result for full samples.

\begin{tabular}{|c|c|c|c|c|c|}
\hline Variables & (1) & (2) & (3) & (4) & (5) \\
\hline \multirow[t]{2}{*}{$\operatorname{lnGDP}$} & $0.305^{* * *}$ & $0.235^{* * *}$ & $0.416^{* * *}$ & $0.331^{* * *}$ & $0.361^{* * *}$ \\
\hline & $(0.0692)$ & $(0.0657)$ & $(0.0559)$ & $(0.0516)$ & (0.0546) \\
\hline \multirow[t]{2}{*}{$\operatorname{lnDIS}$} & $-0.803^{* * *}$ & $-0.654^{* * *}$ & $-0.636^{* * *}$ & $-0.578^{* * *}$ & $-0.575^{* * *}$ \\
\hline & $(0.183)$ & $(0.185)$ & $(0.168)$ & $(0.150)$ & $(0.161)$ \\
\hline \multirow[t]{2}{*}{$\ln E X C$} & 0.0350 & -0.0374 & $-0.0788^{* * *}$ & $-0.105^{* * *}$ & $-0.102^{* * *}$ \\
\hline & $(0.0305)$ & (0.0294) & $(0.0263)$ & $(0.0210)$ & $(0.0238)$ \\
\hline \multirow[t]{2}{*}{$\operatorname{lnOPEN}$} & $-0.392^{* *}$ & -0.191 & $0.420^{* * *}$ & $0.535^{* * *}$ & $0.431^{* * *}$ \\
\hline & $(0.154)$ & $(0.155)$ & $(0.159)$ & $(0.129)$ & $(0.142)$ \\
\hline \multirow[t]{2}{*}{$\operatorname{lnTRA}$} & $0.451^{* * *}$ & $0.432^{* * *}$ & $0.375^{* * *}$ & $0.377^{* * *}$ & $0.406^{* * *}$ \\
\hline & $(0.0552)$ & $(0.0508)$ & (0.0433) & $(0.0424)$ & (0.0440) \\
\hline \multirow[t]{2}{*}{$\operatorname{lnINT}$} & 0.0868 & $0.113^{*}$ & $0.308^{* * *}$ & $0.388^{* * *}$ & $0.322^{* * *}$ \\
\hline & (0.0638) & $(0.0632)$ & (0.0644) & $(0.0574)$ & (0.0624) \\
\hline \multirow[t]{2}{*}{$\ln R E S$} & 0.0320 & -0.0597 & $-0.0964^{* *}$ & $-0.175^{* * *}$ & $-0.161^{* * *}$ \\
\hline & $(0.0465)$ & $(0.0375)$ & $(0.0375)$ & $(0.0478)$ & $(0.0420)$ \\
\hline \multirow[t]{2}{*}{$\operatorname{lnHEA}$} & $1.331^{* *}$ & $2.124^{* * *}$ & $3.163^{* * *}$ & $4.103^{* * *}$ & $3.210^{* * *}$ \\
\hline & $(0.654)$ & $(0.604)$ & $(0.609)$ & $(0.631)$ & $(0.593)$ \\
\hline \multirow[t]{2}{*}{$\operatorname{lnEDU}$} & & $-0.683^{* * *}$ & $-0.890^{* * *}$ & $-0.879^{* * * *}$ & $-0.874^{* * *}$ \\
\hline & & $(0.102)$ & $(0.102)$ & $(0.0874)$ & $(0.0910)$ \\
\hline \multirow[t]{2}{*}{$\operatorname{lnWAG}$} & & & $-0.546^{* * *}$ & $-0.398^{* * *}$ & $-0.540^{* * *}$ \\
\hline & & & $(0.0846)$ & $(0.0911)$ & $(0.0829)$ \\
\hline \multirow[t]{2}{*}{$\operatorname{lnCDR}$} & & & & $1.808^{* * *}$ & \\
\hline & & & & $(0.392)$ & \\
\hline \multirow[t]{2}{*}{$\operatorname{lnODR}$} & & & & & $-0.725^{* * *}$ \\
\hline & & & & & $(0.272)$ \\
\hline \multirow[t]{2}{*}{ Constant } & 3.926 & 1.051 & -4.932 & $-16.90^{* * *}$ & -3.639 \\
\hline & $(4.288)$ & $(4.056)$ & (3.804) & $(4.577)$ & (3.733) \\
\hline region & YES & YES & YES & YES & YES \\
\hline year & YES & YES & YES & YES & YES \\
\hline Observations & 407 & 407 & 407 & 407 & 407 \\
\hline Adj. R-squared & 0.582 & 0.640 & 0.661 & 0.740 & 0.721 \\
\hline
\end{tabular}

Note: ${ }^{* * * *},{ }^{*}$ means respectively the significant level at $1 \%, 5 \%$ and $10 \%$. The values in parentheses mean the standard error of each variable.

This paper studies the impact of human capital heterogeneity on OFDI location choice from four aspects: scale, quality, cost and structure. Human capital structure is divided into two different situations to consider, so five regression models are 
constructed. Based on the control variables, the scale, quality, cost and structure of human capital are gradually added into the five models, in which model (4) and model (5) respectively analyze the child structure and the elderly structure.

It can be seen from the results of the above five regression models that the health level has a significant positive correlation with the location choice of OFDI, indicating that the higher the health level of human capital in the host country, that is, the higher the attendance rate, and the more likely it is to attract the inflow of OFDI. There is a significant negative correlation between the educational level of the host country and the location choice of OFDI, so a higher educational level will reduce the attractiveness of OFDI from Chinese enterprises. This is different from the existing conclusions. There may be two reasons for this: First, the human capital with higher education level in the host country will have higher salary requirements, which will considerably increase the cost of human capital and restrain the entry of overseas investors. Second, the level of education and training in Africa lags behind, so Chinese companies prefer to recruit inexperienced employees to start training from scratch. The wage level of a host country has a significant inhibitory effect on OFDI from China. The regression results of model (4) and model (5) show that the CDR has a significant positive role in promoting OFDI, which indicates that the consumption capacity and demographic dividend of African countries attract Chinese enterprises to invest. The result of ODR is significant negative, that is to say, the ODR in the host country has an inhibitory effect on OFDI of Chinese enterprises. Generally speaking, the higher the ODR in a country, the more serious the population aging situation, which will bring about the decline of labor productivity. Because the pension burden increases the corporate tax and decreases social savings, which will lead to the decrease of social investment.

According to the results of the above mentioned models of the control variables, it can be found that the GDP of the host country presents a significant positive correlation with the OFDI of enterprises, indicating that the market size of the host country is an important factor to attract Chinese enterprises to invest in Africa. The sign of distance cost is negative, and it also passed the significance level of $1 \%$, indicating that enterprises take the distance factor as one of the main factors in the location selection of direct investment in Africa. The exchange rate level of the host country has an unstable effect on OFDI of enterprises, and it generally comes out to have a significant inhibitory effect. The devaluation of the host country's currency will reduce the profits level of Chinese enterprises, thus inhibiting OFDI. The regression results of trade openness and bilateral trade relations also show significant positive effects, which indicates that both trade openness and bilateral trade relations in host countries can promote home countries' enterprises to "go out". Infrastructure level has a significant positive correlation with OFDI, which is consistent with traditional theoretical expectations. The natural resource endowment of the host country shows significant negative correlation, indicating Chinese enterprises' direct investment in Africa is not resource-seeking, which is also inconsistent with western countries' comment that China's investment in Africa is "resource plunder". In order to further explore the impact of human capital heterogeneity of host countries on enterprises' OFDI location selection, samples are divided into the following categories to conduct extended tests. 


\subsection{Extended Test 1: Classification of types according to geographical location}

For analysis, African countries were divided geographically into five regions, namely North Africa, East Africa, West Africa, Southern Africa and Central Africa. (See Table 5)

Table 5. Regional regression results by geographic location

\begin{tabular}{c|cc|cc|cc|cc|cc}
\hline & \multicolumn{2}{|c|}{ North } & \multicolumn{2}{c|}{ East } & \multicolumn{2}{c|}{ West } & \multicolumn{2}{c}{ South } & \multicolumn{2}{c}{ Central } \\
Varibles & $\mathbf{( 1 )}$ & $\mathbf{( 2 )}$ & $\mathbf{( 3 )}$ & $\mathbf{( 4 )}$ & $\mathbf{( 5 )}$ & $\mathbf{( 6 )}$ & $\mathbf{( 7 )}$ & $\mathbf{( 8 )}$ & $\mathbf{( 9 )}$ & $\mathbf{( 1 0 )}$ \\
\hline $\ln H E A$ & $18.86^{* *}$ & $23.85^{* * *}$ & $11.84^{* * *}$ & $14.02^{* * *}$ & $2.480^{*}$ & $4.697^{* * *}$ & $8.615^{* * *}$ & $7.454^{* * *}$ & $19.88^{* * *}$ & 2.489 \\
& $(8.135)$ & $(6.739)$ & $(1.745)$ & $(1.577)$ & $(1.290)$ & $(1.394)$ & $(1.406)$ & $(1.500)$ & $(2.458)$ & $(1.776)$ \\
$\ln E D U$ & $-7.561^{* * *}$ & $-6.363^{* * *}$ & $-1.562^{* * *}$ & $-1.308^{* * *}$ & -0.123 & -0.157 & $-0.396^{* * *}$ & $-0.466^{* * *}$ & $-2.012^{* * *}$ & -0.109 \\
& $(1.131)$ & $(1.028)$ & $(0.303)$ & $(0.248)$ & $(0.202)$ & $(0.240)$ & $(0.120)$ & $(0.136)$ & $(0.236)$ & $(0.365)$ \\
$\ln$ VAG & 0.722 & $0.776^{*}$ & 0.854 & $2.986^{* * *}$ & $-0.862^{* * *}$ & $-1.557^{* * *}$ & $-0.553^{* * *}$ & $-0.518^{* * *}$ & 0.246 & $-0.788^{* * * *}$ \\
& $(0.432)$ & $(0.403)$ & $(0.561)$ & $(0.646)$ & $(0.243)$ & $(0.226)$ & $(0.135)$ & $(0.135)$ & $(0.204)$ & $(0.192)$ \\
$\operatorname{lnCDR}$ & 0.699 & & 0.0749 & & $6.688^{* * *}$ & & -0.125 & & $10.26^{* * *}$ & \\
& $(1.501)$ & & $(1.357)$ & & $(1.187)$ & & $(0.444)$ & & $(1.417)$ & \\
$\operatorname{lnODR}$ & & $-2.585^{*}$ & & $-2.084^{* * *}$ & & -1.834 & & 0.157 & & -1.159 \\
& & $(1.470)$ & & $(0.509)$ & & $(1.241)$ & & $(0.494)$ & & $(1.020)$ \\
Constant & $-100.6^{* *}$ & $-98.53^{* * *}$ & $-67.00^{* * *}$ & $-75.49^{* * *}$ & $-32.76^{* * *}$ & -8.383 & $-29.41^{* * *}$ & $-24.44^{* * *}$ & $-130.1^{* * *}$ & -12.86 \\
& $(39.84)$ & $(25.11)$ & $(14.11)$ & $(10.69)$ & $(6.520)$ & $(6.315)$ & $(7.120)$ & $(6.148)$ & $(15.53)$ & $(11.64)$ \\
Control var. & YES & YES & YES & YES & YES & YES & YES & YES & YES & YES \\
region & YES & YES & YES & YES & YES & YES & YES & YES & YES & YES \\
year & YES & YES & YES & YES & YES & YES & YES & YES & YES & YES \\
Observations & 55 & 55 & 66 & 66 & 110 & 110 & 110 & 110 & 66 & 66 \\
Adj.R- & 0.980 & 0.981 & 0.973 & 0.957 & 0.940 & 0.931 & 0.907 & 0.925 & 0.933 & 0.882 \\
squared & & & & & & & & & & \\
\hline
\end{tabular}

Note: ${ }^{* * *},{ }^{* *},{ }^{*}$ means respectively the significant level at $1 \%, 5 \%$ and $10 \%$. The values in parentheses mean the Standard Error of each variable.

In North Africa, East Africa, West Africa and Southern Africa, the health level shows significant positive correlation with home country's OFDI, indicating that the human capital scale of host country has a positive role in promoting OFDI from China. The health level in Central Africa is not stable. After including CDR, the health level of the host country has a significant promotion effect on the OFDI of enterprises, while after the inclusion of the ODR, the health level shows no significant impact on the location choice of OFDI.

In North Africa, East Africa and Southern Africa, the host country education level and enterprise OFDI present a significantly negative correlation relationship. In the Central African region, after adding CDR, the education level shows significantly negative return results that were abnormal and different from existing research. The possible reason has been discussed in the full sample analysis, which is the higher education level, the higher local people demand to be paid, which will increase the investment cost of enterprises at some level. Because education in these regions is way behind China, enterprises are relatively more willing to take the initiative to train the employees on their own to participate in work. In China's direct investment in West Africa, the effect of education on OFDI is negative, but it does not pass the significance level of $10 \%$, which indicates that enterprises' investment in West Africa does not consider the quality of human capital.

In West Africa, Southern Africa and Central Africa, wage level has a significant inhibitory effect on OFDI of enterprises, showing that OFDI of enterprises are more inclined to choose countries or regions with lower human capital cost. In North Africa and East Africa, when the ODR is added, the regression result of wage level is significant positive correlation, and the ODR is negatively correlated with the investment of enterprises, indicating that the countries with a low degree of aging problem will promote the human capital cost to attract the inflow of Chinese enterprises' OFDI. In West and Central Africa, the CDR is significant positive correlation, indicating that the consumption potential and demographic dividend of host countries have a positive role in promoting OFDI of enterprises. However, in North Africa and East Africa, the symbol of CDR is different, and the significance test of $10 \%$ is not passed, representing that CDR is not a 
decisive factor for enterprises to make direct investment decisions in these regions. Looking at the regression results of the ODR, except for North Africa and East Africa, where the sign of the ODR is significant negative correlation, the ODR in other regions does not pass the significance test of $10 \%$, indicating that China only considers the host country's aging level when investing in North Africa and East Africa.

\subsection{Extended Test 2: Classification of types by income level}

The income level of African people presents a greater differentiation. In 2013, the World Bank announced the latest income standard: high-income countries with income above USD 12,616; between USD 4,086 and USD 12,615 is the middle- and high-income countries; between USD 1,036 and USD 4,085 is the low- and middle-income countries; countries with per capita GNI below USD 1,035 are low income countries. According to the income standard reported by World Bank, to test how Chinese enterprises' OFDI were influenced by the heterogeneity of human capital under different host country income level, and considering the high income countries in Africa sample size is small, so in this paper, middle- and high-income countries are combined with high income countries into the same group for analysis, which all belong to the high-income group. The whole sample was divided into three groups: low income group, middle income group, as well as high income group. (See Table 6)

Table 6. Regression results by region income level

\begin{tabular}{|c|c|c|c|c|c|c|}
\hline Variables & \multicolumn{2}{|c|}{ Low income group } & \multicolumn{2}{|c|}{ Middle income group } & \multicolumn{2}{|c|}{ High income group } \\
\hline $\operatorname{lnHEA}$ & $\begin{array}{c}12.60^{* * * *} \\
(1.008)\end{array}$ & $\begin{array}{l}6.999^{* * * *} \\
(0.899)\end{array}$ & $\begin{array}{c}-3.209^{* * *} \\
(0.727)\end{array}$ & $\begin{array}{l}-4.274^{* * * *} \\
(0.688)\end{array}$ & $\begin{array}{r}-12.06^{* * * *} \\
(1.868)\end{array}$ & $\begin{array}{c}-10.87^{* * * *} \\
(1.929)\end{array}$ \\
\hline $\operatorname{lnEDU}$ & $\begin{array}{c}-0.480^{* * *} \\
(0.128)\end{array}$ & $\begin{array}{l}-0.278^{*} \\
(0.168)\end{array}$ & $\begin{array}{l}-0.155 \\
(0.148)\end{array}$ & $\begin{array}{c}-0.295^{* *} \\
(0.146)\end{array}$ & $\begin{array}{r}0.670^{* * * *} \\
(0.231)\end{array}$ & $\begin{array}{c}0.808^{* * *} \\
(0.189)\end{array}$ \\
\hline $\ln W A G$ & $\begin{array}{c}-0.517^{* * *} \\
(0.196)\end{array}$ & $\begin{array}{l}-0.0467 \\
(0.238)\end{array}$ & $\begin{array}{l}1.002^{* * *} \\
(0.272)\end{array}$ & $\begin{array}{c}0.869^{* * *} \\
(0.264)\end{array}$ & $\begin{array}{c}1.273^{* * *} \\
(0.398)\end{array}$ & $\begin{array}{c}0.751^{* * * *} \\
(0.230)\end{array}$ \\
\hline $\operatorname{lnCDR}$ & $\begin{array}{c}5.968^{* * * *} \\
(0.622)\end{array}$ & & $\begin{array}{c}5.087^{* * * *} \\
(0.869)\end{array}$ & & $\begin{array}{c}2.766^{* * * *} \\
(0.674)\end{array}$ & \\
\hline $\operatorname{lnODR}$ & & $\begin{array}{l}-0.953 \\
(0.619)\end{array}$ & & $\begin{array}{c}-2.282^{* * *} \\
(0.447)\end{array}$ & & $\begin{array}{c}-2.031^{* * *} \\
(0.433)\end{array}$ \\
\hline Constant term & $\begin{array}{c}-79.87^{* * *} \\
(6.715)\end{array}$ & $\begin{array}{c}-37.03^{* * * *} \\
(6.271)\end{array}$ & $\begin{array}{l}-4.842 \\
(8.166)\end{array}$ & $\begin{array}{c}29.03^{* * * *} \\
(3.398)\end{array}$ & $\begin{array}{c}17.23 \\
(14.06)\end{array}$ & $\begin{array}{c}45.66^{* * * *} \\
(10.90)\end{array}$ \\
\hline $\begin{array}{l}\text { Control var. } \\
\text { region } \\
\text { year }\end{array}$ & $\begin{array}{l}\text { YES } \\
\text { YES } \\
\text { YES }\end{array}$ & $\begin{array}{l}\text { YES } \\
\text { YES } \\
\text { YES }\end{array}$ & $\begin{array}{l}\text { YES } \\
\text { YES } \\
\text { YES }\end{array}$ & $\begin{array}{l}\text { YES } \\
\text { YES } \\
\text { YES }\end{array}$ & $\begin{array}{l}\text { YES } \\
\text { YES } \\
\text { YES }\end{array}$ & $\begin{array}{l}\text { YES } \\
\text { YES } \\
\text { YES }\end{array}$ \\
\hline Observations & 165 & 165 & 132 & 132 & 99 & 99 \\
\hline Adj. R-squared & 0.891 & 0.888 & 0.964 & 0.932 & 0.912 & 0.893 \\
\hline
\end{tabular}

Note: ${ }^{* * *}, * *,{ }^{*}$ means respectively the significant level at $1 \%, 5 \%$ and $10 \%$. The values in parentheses mean the Standard Error of each variable.

In the low income group, health level has a positive effect on China's OFDI, indicating that the human capital scale in host countries is attractive to Chinese enterprises' capital inflow. In the middle income group and high income group, the health level of the host country and China's OFDI inflows present a negative correlation. The possible reason is that a higher level of health to some extent, indicates the social welfare of host country is higher, then it would need to charge higher taxes from enterprise to official department to maintain a higher level of welfare, thus inhibiting the Chinese enterprise capital inflows.

Education level has a significant inhibiting effect on China's OFDI in the low income group and middle income group, while education level has a significant promoting effect on China's OFDI in high income group. To a certain extent, a country's education level can reflect the country's human resources and innovation ability. In low income group and middle income group, economic strength is relatively weak, thus the welfare level is 
reasonably low, causing serious brain drain. And for the high income group, employee welfare level is relatively high, which can largely avoid brain drain. Multinational enterprises can benefit from local talents in host countries. Therefore, in the high income group, a higher education level can attract Chinese enterprises to invest.

In the low income group, when the CDR index is added, the sign of wage level is significantly negative, indicating that the high cost of human capital will inhibit the inflow of OFDI. In the middle income group and high income group, the wage level has a significant promoting effect on FDI, that is, the higher the cost of human capital is, the more attractive it is to FDI, which is different from the traditional theory. The possible reason is that the wage level of the high income group can somewhat reflect the market opportunities of that country, and China's OFDI prefers countries with greater market opportunities. In these three groups, the CDR is significantly positively correlated with the size of China's OFDI, indicating that the income level of the host country does not affect enterprises' preference for the consumption potential and demographic dividend of host country, when making investment decisions. The signs of ODR in these three groups are all negative, but it fails to pass the significance test of $10 \%$ in low-income countries, indicating that the location selection of China's OFDI in low-income African countries does not consider ODR.

What can be seen from above is that the heterogeneity of human capital in different regions of Africa has significant differences in influencing the investment decisions of Chinese enterprises, and the empirical results have high guiding value for the investment practices of enterprises.

\section{Robustness Checks}

\subsection{Instrumental Variables Robust Test}

As there may be a bidirectional causality between human capital heterogeneity in host countries and the OFDI of Chinese enterprises, further consideration is needed in estimation methods. In the above analysis, only the influence of various dimensions of human capital on enterprise investment is tested, but the influence of enterprise investment on human capital level of host country has not been considered. For example, to attract capital inflow from China can not only promote the improvement of local economic development, but also absorb the advanced technology and management skills brought by the investment from Chinese enterprises, thus exerting an impact on local human capitals. According to the study of Liu et al. [37] and Luo et al. [38], it is believed that FDI will impact the wage level of workers. Therefore, in order to solve the endogeneity caused by the bidirectional causality between human capital heterogeneity and OFDI, instrumental variable method should be used for estimation. The selection principle of instrumental variables is not only closely related to endogenous explanatory variables, but also has to ensure the instrumental variables are strictly exogenous. Referring to the research method of Yuan et al. [39], the lag period treatment of human capital heterogeneity is taken as instrumental variables. First, the Two-Stage Least Square Method (2SLS) was used to estimate the model. The results showed that the F-statistic of the first-stage regression was much larger than the critical value of 10 , so the selection problem of "weak instrumental variables" could be excluded, that is, the instrumental variables were highly correlated with the endogenous explanatory variables. In this paper, "Limited Information Maximum Likelihood Method (LIML)" is used to estimate the model. The results are shown in columns (1) and (2) of Table 7. Only the second stage regression results are reported in the table, which are basically consistent with the fullsample test results, indicating that the conclusions of this paper are robust.

\subsection{Further Robustness Tests Discussion}

\subsubsection{Robustness test of the lag one period treatment of robust test}

Considering that the lag period of human capital heterogeneity may have a lasting impact on enterprise investment, this paper makes robustness test from index setting. Each dimension of human capital is lagged for one period, and the FGLS model is again used to estimate. The test results are shown in columns (3) and (4) of Table 7. It is found 
that the influence of human capital heterogeneity on enterprise investment in Africa after lag period treatment is basically consistent with the regression results of the full-sample test, except that the size of the regression coefficient changes slightly, indicating that the results are robust.

\subsubsection{Robustness test of temporal dimension heterogeneity}

From 2007 to 2009, the outbreak of the global financial crisis had a significant negative impact on the economic development of all countries in the world, as well as on the level of human capital in Africa and the location selection of Chinese enterprises' OFDI. Generally speaking, financial crisis will have a huge impact on employment by local human capital relocation, resulting in the increase of unemployment rate, especially the increase of structural unemployment. Therefore, the scale, cost, quality and structure of human capital in Africa will be adversely affected by the financial crisis. Considering that time dimension heterogeneity may lead to inaccurate research results, sample data from 2007 to 2009 are removed in this paper, and sub-sample data from 2010 to 2017 are intercepted for regression analysis again. Results such as table 7 (5), (6) shown in the column, found that the coefficient of each dimension of human capital is larger than above all sample analysis, and almost no difference regarding symbols and significance. The financial crisis will reduce the utility size of the impact of human capital heterogeneity on China's enterprise OFDI, but will not change the direction of utility, so again the previous conclusion is robust.

Three different methods were used to carry out the robustness analysis, and the results fully show that the conclusions of this paper are reliable. As space is limited, the robustness test results will not be repeated one by one.

Table 7. The results of robust test

\begin{tabular}{|c|c|c|c|c|c|c|}
\hline Variables & Instrume & Variable & $\begin{array}{c}\text { Control } \\
\text { variable } \\
\text { (3) }\end{array}$ & $\begin{array}{l}\text { Lag period } \\
\text { (4) }\end{array}$ & $\begin{array}{r}\text { Time } \\
\text { dimension } \\
\text { (5) }\end{array}$ & $\begin{array}{c}\text { Heterogeneity } \\
\text { (6) }\end{array}$ \\
\hline $\operatorname{lnHEA}$ & $\begin{array}{c}1.984^{* * * *} \\
(0.741)\end{array}$ & $\begin{array}{l}1.131^{*} \\
(0.681)\end{array}$ & $\begin{array}{c}3.855^{* * * *} \\
(0.614)\end{array}$ & $\begin{array}{c}2.942^{* * *} \\
(0.579)\end{array}$ & $\begin{array}{c}4.935^{* * * *} \\
(0.585)\end{array}$ & $\begin{array}{c}3.686^{* * *} \\
(0.687)\end{array}$ \\
\hline $\operatorname{lnEDU}$ & $\begin{array}{c}-0.604^{* * *} \\
(0.116)\end{array}$ & $\begin{array}{c}-0.626^{* * *} \\
(0.117)\end{array}$ & $\begin{array}{l}-0.850^{* * * * *} \\
(0.0893)\end{array}$ & $\begin{array}{c}-0.849^{* * * *} \\
(0.0888)\end{array}$ & $\begin{array}{c}-0.863^{* * *} \\
(0.0963)\end{array}$ & $\begin{array}{c}-0.845^{* * *} \\
(0.0912)\end{array}$ \\
\hline $\ln W A G$ & $\begin{array}{l}0.0224 \\
(0.112)\end{array}$ & $\begin{array}{l}-0.185^{*} \\
(0.102)\end{array}$ & $\begin{array}{l}-0.380^{* * * *} \\
(0.0917)\end{array}$ & $\begin{array}{c}-0.510^{* * * *} \\
(0.0813)\end{array}$ & $\begin{array}{l}-0.160 \\
(0.100)\end{array}$ & $\begin{array}{l}-0.430^{* * * *} \\
(0.0862)\end{array}$ \\
\hline $\operatorname{lnCDR}$ & $\begin{array}{c}2.446^{* * *} \\
(0.505)\end{array}$ & & $\begin{array}{c}1.821^{* * *} \\
(0.399)\end{array}$ & & $\begin{array}{c}2.500^{* * * *} \\
(0.416)\end{array}$ & \\
\hline $\operatorname{lnODR}$ & & $\begin{array}{c}-1.658^{* * * *} \\
(0.312)\end{array}$ & & $\begin{array}{c}-0.923^{* * *} \\
(0.271)\end{array}$ & & $\begin{array}{c}-0.691^{* * *} \\
(0.252)\end{array}$ \\
\hline Constant & $\begin{array}{l}-10.95^{*} \\
(5.673)\end{array}$ & $\begin{array}{l}9.041^{* *} \\
(4.354)\end{array}$ & $\begin{array}{c}-15.94^{* * *} \\
(4.601)\end{array}$ & $\begin{array}{l}-2.047 \\
(3.677)\end{array}$ & $\begin{array}{c}-19.77^{* * *} \\
(4.496)\end{array}$ & $\begin{array}{l}-3.040 \\
(4.074)\end{array}$ \\
\hline Control var. & YES & YES & YES & YES & YES & YES \\
\hline region & YES & YES & YES & YES & YES & YES \\
\hline year & YES & YES & YES & YES & YES & YES \\
\hline Observations & 407 & 407 & 407 & 407 & 296 & 296 \\
\hline Adj. R-squared & 0.574 & 0.567 & 0.731 & 0.722 & 0.757 & 0.696 \\
\hline
\end{tabular}

Note: ${ }^{* * *},{ }^{* *},{ }^{*}$ means respectively the significant level at $1 \%, 5 \%$ and $10 \%$. The values in parentheses mean the Standard Error of each variable.

\section{Conclusions}

As a basic production factor, human capital plays an important role in a country's economic development, and its heterogeneity has undoubted influence on foreign investment. Based on the panel data of Chinese firms' OFDI in 37 African countries from 2007 to 2017, this paper focuses on examining the impact of host country human capital heterogeneity on firms' OFDI location selection by using the FGLS estimation method. Through the full sample tests, the research finds that: (1) The health level of human capital is positively correlated with the location choice of OFDI, that is, the larger the scale of human capital measured by health level, the more it will attract the OFDI of Chinese enterprises; (2) The influence of education level on OFDI of enterprises in host countries 
is different from existing research conclusions, which is the higher the quality of human capital measured by education level, the lower the investment of Chinese enterprises in Africa. The explanation is that human capital with high education level has a higher wage requirement, thus indirectly increasing the total cost of enterprises. This, to some extent, exposes the low-tech reality of corporate investment in Africa; (3) Chinese enterprises invest in Africa to seek cheap human capital, and the wage level of the host country has a restraining effect on the inflow of OFDI. (4) From the perspective of human capital structure, the CDR could represent a country's consumption capacity and economic growth potential, and promotes enterprises OFDI, while the ODR has a negative impact on the inflow of OFDI of enterprises. Finally, the robustness of the above empirical results has been tested from different angles, and the reliability of the conclusions has also been confirmed.

In addition, the extended test was carried out in two different aspects. First, Africa is divided into regions according to geographical location. The results show that the scale of human capital in host countries is positively correlated with the investment of enterprises in all regions of Africa. The quality of human capital in these five regions also restrains the inflow of OFDI. When examining the impact of human capital cost on China OFDI, investment in West Africa, Southern Africa and Central Africa shows an inhibitory effect, while investment in North Africa and East Africa shows an opposite effect. The CDR has positive impact only when enterprises are investing in West and Central Africa, while the ODR only has negative impact on investment in North and East Africa. Secondly, the study divides African countries into regions based on income level and finds that the scale of human capital in host countries is significantly positively correlated with the investment of Chinese enterprises in low income countries, but negatively correlated with the investment to middle income and high income countries. The quality of human capital has a positive impact when investing in high income countries, but has a negative impact on the investment of low income and middle income countries. The high cost of human capital inhibits investment in low income countries, but promotes investment in middle income and high income countries. The CDR has a positive effect on investment in all regions, while the ODR has a restraining effect on enterprise investment only in middle income and high income countries. On the whole, the results of the extended tests are mostly consistent with the conclusions of the full-sample analysis, which fully demonstrates the robustness of the conclusions of this study.

Based on the above research results, the following conclusions are put forward: (1) Investing in Africa, Chinese enterprises should attach importance to Corporate Social Responsibility, actively participate in local health infrastructure construction, pay attention to environmental protection and humanistic care for employees. (2) During the sample period, the high level of education inhibits the inflow of OFDI from Chinese enterprises, which may reflect the low technical content when Chinese enterprises are investing in Africa, contrary to the concept of sustainable development of investment in Africa; the key is to improve the technical content of enterprises by increasing skills training for local employees in Africa. (3) Manufacturing industries in the middle of the "smile curve" can seek cheap human capital for OFDI in the short term, but with the gradual maturity of products in the local market, their R\&D and marketing should adapt to the needs of industrial transformation and upgrading, and constantly improve their added value. (4) In the sample period, the expansion of CDR in African countries attracts enterprise investment, but as time goes on, the aging problem in these countries will become very serious, which has an adverse impact. Therefore, enterprises should make reasonable investment decisions in advance.

Author Contributions: The authors worked together for this research. Conceptualization, D.Z., M.C. and Y.W.; methodology, software validation, and resources, C.G. and D.Z.; data analysis, C.G.; writing-original draft preparation, C.G. and Y.W.; writing-review and editing, C.G., D.Z., M.C. and Y.W. All authors have read and agreed to the published version of the manuscript

Funding: This research received no external funding.

Institutional Review Board Statement: Not applicable.

Informed Consent Statement: Not applicable. 
Data Availability Statement: Please contact corresponding author.

Acknowledgments: The authors thank the editor and anonymous reviewers for their useful comments and suggestions.

Conflicts of Interest: The authors declare no conflict of interest.

\section{References}

1. Walz, U. Transport Costs, Intermediate Goods, and Localized Growth. Reg Sci Urban Econ. 1996, 26, 671-695.

2. Almeida, P.; Kogut, B. Localization of Knowledge and the Mobility of Engineers in Regional Networks. Manage Sci. 1999, $45,905-917$.

3. Bellante, D. The North-South Differential and the Migration of Heterogeneous Labor. Am Econ Rev. 1979, 69, 166-175.

4. Sattinger, M. Assignment Models of the Distribution of Earnings. J Econ Lit. 1993,31, 831-880.

5. Dunlevy, J.A. Factor Endowments, Heterogeneous Labor and North-South Migration. South Econ J, 1985, 52, 446-459.

6. Li, Z.M. Human Capital: A Theoretical Framework and Its Explanation of Some Problems in China. Econ Sci Press. 1999.

7. Vanhonacker, W. R; Pan, Y. The Impact of National Culture, Business Scope, and Geographic Location on Joint Venture Operations in China. J Int Marketing. 1997, 5, 11-30.

8. Majocchi, A.; Strange, R. The FDI Location Decision: Does Liberalization Matter? Trans Corpor. 2007, 12, 1-40.

9. Behname, M. FDI Localization, Wage and Urbanization in Central Europe. Rom Econ J. 2013, 16, 23-35.

10. Jaeck, L.; Kim, S. FDIDeregulation versus Labor Market Reform: A Political Economy Approach. Atl Econ J. 2018, 1, 1-17.

11. Li,J.H.; Wang, L.Y.; Guo, L. Human Capital and Foreign Direct Investment. Empirical Evidence from China's Provincial Panel Data. Macroecon. 2019, 3, 134-146.

12. Lin, F.Q. Labour Quality and Inward FDI: A Firm-level Empirical Study in China. China World Econ. 2011, 19, 68-86.

13. Feng, W.; Shao, J.; Xu, K.N. Market Size, Labor Cost and FDI: Based on the Study of Panel Data of Our Provinces from 1990 to 2009. Nankai Econ Stud. 2011,6,3-20.

14. Wu, X.M.; Huang, C.T. The Motives of Foreign Direct Investments by Chinese Enterprises: A Comparative Study between Upstream and Downstream Investments. China Ind Econ. 2016, 1,99-113.

15. Bloom, D.E; Canning, D. The Health and Wealth of Nations. Science, 2000, 287, 993-994.

16. Garcia-Gomez, P.;Jones, A.M.; Rice, N. Health Effects on Labour Market Exits and Entries. Labour Econ. 2010, 17,62-76.

17. Bhargava, A. Nutrition, Health and Economic Development: Some Policy Priorities. Food Nutr Bull. 2001, 22, $173-177$.

18. Savedoff, W.D.; Schultz, T.P. Earnings and the Elusive Dividends of Health. Soc Sci Electron Publ, 2011, 39, 85-100.

19. Alsan, M.; Bloom, D.E;Canning, D. The Effect of Population Health on Foreign Direct Investment Inflows to Low-and Middle-income Countries. World Dev. 2006,34,613-630.

20. Wang, Y.Q.; Du, J.L.; Wang, K. The Determinants of Location Choices of China's ODI: Institutions, Taxations and Resources. Econ Res J. 2014, 12, 126-142.

21. Zhang, H.F.; Yao, X.G.; Zhang J.S. The Impact of School Quality on Regional Labor Productivity. Econ Res J. 2010,7,57-67.

22. Wang, X.L.; Fan, G. Income Inequality in China and Its Influential Factors. Econ Res J. 2005, 10, $24-36$.

23. Coulombe, S.; Tremblay, J.F. Education, Productivity and Economic Growth: A Selective Review of the Evidence. Int Prod Monit. $2009,18,3-24$.

24. Wang, P. The Impact of Labor age and Education Structure on Economic Growth: From the Perspective of the Life Cycle of Human Capital Stock. Macroecon. 2015, 1,52-57+115.

25. He, X.Q.; Wang, L.X. Empirical Analysis on Spatial Linkages in FDI across China. Econ Res J. 2008, 11, 137-150.

26. Xu, K.N.; Chen, J. Location Determinants of Value Chain of Transnational Corporations. Econ Res J. 2008, 3, 138-149.

27. Cheng, L.K; Kwan, Y.K. What Are the Determinants of the Location of Foreign Direct Investment: The Chinese Experience. J Int Econ. 2000, 51, 379-400.

28. Liu, K.;Zhu, Y.Z; Zhan S.M. Labour Force Heterogeneity and FDI Location: An Empirical Research Based on Panel Data of 69 Countries. Int Bus. 2016, 5, 100-112.

29. Gao, H.Y.; Wang, S.J; Lv, X. The impact of population aging and its implications D]. Insu Stud, 2015, 4, 93-97.

30. Mason, A. Population and the Asian Economic Miracle. Honolulu: East-West Center. 1997, 43, 1-4.

31. Bloom, D.E.; Williamson, J.G. Demographic Transitions, Human Resource Development and Economic Miracles in Emerging Asia. World Bank Econ Rev. 1998, 12, 419-455.

32. Wang, W. Economic Growth, Demographic Transformation and China's High Savings. China Econ Quart. 2009, 10, 134-146.

33. Wang, W. Demographic Change and Chinese Trade Surplus: Theoretical and empirical analysis. J Financ and Econ. 2012, 8, 26-37.

34. Jiang, D.C.; Zhang, Q.C. Direct Investment of the USEconomy in China. Journal World Econ. 2011, 5, $26-41$.

35. Stoiana, C;; Filippaios, F. Dunning's Edectic Paradigm: A Holistic, Yet Context Specific Framework for Analysing the Determinants of Outward FDI: Evidence from International Greek Investment. Int Bus Rev. 2008, 17, 349-367.

36. Li, L; Zheng, S.Y. Is China's Outward FDI Seeking Resources? J Int Trade. 2012, 2, 146-157.

37. Liu, C; Ge, S.Q.; Luo, W. FDI, Heterogeneous Labor Market and Wage Improvement in Cities. J Int Trade. 2018, 1, 112-122.

38. Luo, W.; Liu, C;; Ge, S.Q. Spillover and Linkage Effects of FDIs on Manufacturing Wages in China. JWorld Econ. 2018, 5, 147-172.

39. Yuan, Q.G.; Gao, C; Yan, S.L. African Governments' Governance Level and the Location Selection of Chinese Enterprises' OFDI. World Econ Stud. 2018, $10,121-134$ 